\title{
Determinants of Corporate Hedging Practices in Malaysia
}

\author{
Dr. Rashid AMEER \\ Accounting Research Institute and Faculty of Accountancy \\ Universiti Teknologi MARA (UiTM) \\ Shah Alam, Selangor, 40450, Malaysia \\ Tel: 60-3-5521-1711Ｅ-mail: rashidameer@salam.uitm.edu.my
}

\begin{abstract}
This paper examines the impact of the firm specific factors on the use of derivative instruments for Malaysia firms. We find that there is a significant relationship between the use of derivatives and foreign sales, liquidity, firm growth, managerial ownership and size. Our findings suggest that only a few listed Malaysian firms have appropriate understanding of the derivatives instruments to mitigate risks in international business environment. Most Malaysian managers seem to be risk averse and do not understand the upside of taking position in the derivatives markets.
\end{abstract}

Keywords: Hedging, Risk management, Derivatives, Internationalization, Malaysia

\section{Introduction}

Risk management has been a matter of continuous concern to most corporations since the fall of Bretton Woods System in the middle of 1970s; in particular, the changes in the exchange rates have been a major risk to firms involved in the imports and exports (Bartram, 2008). It is not surprising that most of the previous studies have focused predominantly on the firm's foreign currency risk (Hagelin 2003; Allayannis and Ofek, 2001; Géczy et al. 1997), besides interest rate risk (Graham and Rogers, 2000; Carcano and Foresi, 1997; Mian 1996). And recently other market risks such as commodity risk, (see e.g., Lien and Yang, 2008; Alizadeh, Nomikos, and Pouliasis, 2008) and other non-financial risks such as information processing, technological, strategic and leadership risk (Linsley and Shrives, 2006) has become centre of attention. However, this empirical evidence regarding the choice of hedging instruments and determinants of foreign exchange risk hedging seems to reflect decision making of managers in the developed countries context which have found to have less information asymmetry, efficient market for corporate control, better institutional and legal systems.

In this paper, we argue that determinants of hedging practices outside the developed world would be different due to unique firm specific characteristics. A few studies have investigated market risk disclosure practices of the firms in Asia-Pacific region. For instance, $\mathrm{He}$ and $\mathrm{Ng}$ (1998) examined the foreign exchange exposure of Japanese multinational corporations; Nguyen and Faff (2003), Chalmers and Godfrey (2000) and Chalmers (2001) investigated the impact of derivatives reporting for firms in Australia, and $\mathrm{Hu}$ and Wang (2006) examined usage of derivatives among firms in Hong Kong. A feature of this study that distinguishes it from previous empirical tests of foreign currency hedging is that it uses variables that uniquely capture the governance system and mechanism in an emerging market. We argue that by including ownership variables, our paper builds on literature that have examined the effect of ownership structure on the determinants of risk management strategies and influence of managerial incentives and external monitoring on the decision to use derivatives (see Hagelin, Holmen, and Prambord, 2006; Whidbee and Wohar, 1999). Furthermore, the robustness of the findings of the previous studies that rely on developed countries sample need to be examined against evidence from other newly industrialized countries such as Malaysia.

Thus, a major motivation behind this study is to investigate the factors that influence the demand of the derivatives, in particular, foreign exchange and interest rate derivatives in the case of Malaysian listed firms. Furthermore, Malaysian Accounting Standards Board (MASB) introduced FRS132: Financial Instruments Disclosure and Presentation (IAS32) for the first time to be adopted by Malaysian firms for financial periods beginning or after 2006. This standard requires the type of market risk being faced by listed companies in Malaysia to be disclosed, and it can be seen as an attempt to make financial reporting standards in Malaysia at par with international financial reporting standards. Thus, we argue that our study is timely to provide evidence of the determinants of foreign exchange risk hedging practices among Malaysian firms.

\section{Theoretical framework and hypotheses development}

Derivatives are an integral part of firms' risk management policy. Market risk is defined as the risk of loss arising from the adverse changes in the market rates and prices such as the interest rates, currency exchange rates, 
commodity prices, or equity prices. Smith and Stulz (1985) propose that for value maximizing firms hedging is part of overall corporate financing policy. They suggest that hedging can affect firm value, through changes in tax liabilities, changes in stakeholder contracting costs, or interdependencies between the choice of financial policy and future real investment decisions. This implies that hedging can increase a firm's value by simultaneously reducing external claims such as taxes paid to government; bankruptcy costs (both direct and indirect); and/or agency costs to align managerial interests with the interests of capital suppliers.

Hedging can reduce underinvestment costs (see Myers 1977; Bessembinder, 1991) since it reduces the probability of financial distress by shielding future stream of cash flows from the changes in the exchange rates. According to Froot, Scharfstein, and Stein (1993) hedging ensure that a firm has sufficient internal funds which would enable it to avoid unnecessary fluctuations in either investment spending or external financing and so increases firm value. Froot et al. (1993) argue that variability in cash flows will result in variability in the amount of investment. A decrease in planned investment means that the firm is foregoing positive net present value projects and since it has insufficient internal funds the firm is forced to raise costly external finance. In both Bessembinder (1991) and Froot et al. (1993) analysis the costs of underinvestment will be greater for those firms with more growth options.

Alternatively, firm could lower the likelihood of financial distress by possessing more liquid assets ensuring that funds will be available to pay debt claims. Also firms with higher levels of liquidity will have less need to access costly external financing to fund their investment programme. Nance, Smith, and Smithson (1993), however, posit that corporations can mitigate expected costs of financial distress and agency costs by maintaining a larger short-term liquidity position in terms of having a lower dividend payout ratio or a higher quick ratio. In order to test financial distress cost (underinvestment) and growth option hypotheses.

Thus, we hypothesize that

H1- there is a positive relationship between long-term debt ratio and derivatives.

H2 -there is a positive relationship between the growth options and derivatives.

\section{H3- there is a negative relationship between liquidity and derivatives.}

Cash flow models of foreign exchange exposure suggest that the foreign exposure should be related to net foreign currency revenues (total revenues minus costs) - higher foreign sales would lead to higher use of currency derivatives. Firms with greater variation in cash flows or accounting earnings resulting from exposure to exchange rate risk have greater potential benefits of foreign currency hedging. The degree to which a firm's cash flows are affected by exchange rate changes should depend on the nature of its activities, such as the level of export and import activity, its involvement in foreign operations, its competitors currencies, and the competitiveness of its input and output markets. Thus, given the exchange rate uncertainty associated with the value of cash flows at a future data that is denominated in the foreign currency can be hedged perfectly in the forward market if the foreign currency value of the cash flow is known with certainty.

H4- there is a positive relationship between the foreign sales and derivatives.

H5- there is a positive relationship between the cash flow volatility and derivatives.

It has been argued that if a firm faces a convex tax function, then hedging reduces the volatility of taxable income and the firm's expected tax liability. For a firm facing some form of tax progressivity, when taxable income is low, its effective marginal tax rate will be low; but when income is high, its tax rate will be high. If such a firm hedges, the tax increase in circumstances where income would have been low is smaller than the tax reduction in circumstances where income would have been high, thus lowering expected taxes (Graham and Smith, 1999, p. 2241). We test for tax hypothesis:

H6- there is a positive relationship between tax losses and derivatives.

In addition, we suggest that corporate ownership structure also affect the desirability of hedging. A manager's wealth function is a concave or convex function of the firm value depending upon his/her investment in the firm's equity. As a manager's investment in the firm increases, his/her wealth function will increasingly resemble equity holders' payoff function that is linear function of firm value over the range of possible outcomes. As managers' investment in the firm increase, his/her wealth becomes increasingly linear function of firm value. Poorly diversified managers with linear wealth function have incentives to engage in more hedging. However, if managers are also given share options their wealth function becomes convex because of the convex payoff structure of options. Previous studies such as Whidbee and Wohar (1999) and Fok, Carroll and Chiou (1997) found that managerial and institutional ownership structure has significant influence on the corporate hedging 
decisions. We argue that in the developing countries such as Malaysia, the effect of ownership structure would be unique compared to the developed markets such as the U.S because of less dispersed ownership and poor portfolio risk diversification of managers.

The institutional investors, on the other hand, manage portfolios to achieve maximum risk diversification therefore we should expect them to reduce their ownership in those firms which have any kind of market risk. Monitoring and discipline of a manager will also affect the relation between the manager's wealth and firm value (Whidbee and Wohar, 1999). Based on these arguments, closely monitored managers should be more likely to hedge. We test two ownership hypotheses:

H7: there is a positive relationship between managerial ownership and derivatives.

H8: there is a negative relationship between institutional ownership and derivatives.

It has also been suggested that there is a relationship between firm size and hedging. There are, however, competing arguments for either a positive or negative relation between firm size and hedging activity. The negative relationship between the firm size and direct bankruptcy costs suggests that the smaller firms have greater incentives to hedge. Smaller firms are also faced with greater information asymmetries and higher financing transaction costs which are likely to make external financing more expensive for smaller firms and therefore hedging more likely. However, smaller firms might lack the technology and expertise to effectively use derivatives to manage their risk exposures. Conversely, hedging activity exhibits significant information and transaction cost scale economies implying that larger firms are more likely to hedge. Thus, we argue that there is an ambiguous relationship between the firm size and derivatives.

\subsection{Measurement of explanatory variables}

The annual firm-level financial data was obtained from Thomson Worldscope to calculate explanatory variables. In line with previous studies, we use a firm's long-term debt to total assets ratio denoted by $(D E B T)$. It has been argued that this variable is linked to probability that a firm would face costs of financial distress and hence a greater desire to engage in hedging activities. A firm's growth options are not directly observable therefore we use three different proxies for growth options - capital expenditure divided by total sales (CAPEX); the price earnings ratio $(P E)$ and the sum of market value of equity and book value of debt to total assets as proxies for growth options in the firms' investment opportunity denoted by $(M T B)$. FS is the ratio of the foreign sales to total sales at the end of year. Cash flow volatility $(C F V)$ is measured by standard deviation of operating income before depreciation. We use two proxies for firm liquidity as in earlier studies, $(D P S)$ is the dividends per share and $(Q A)$ is the ratio of quick assets to total current assets as proxies for firm liquidity. We use log of firms' total assets as proxy for firm size.

The shareholding data at the end of year was obtained from shareholders statistics reported in the annual report each year between 2003 -2007. These statistics show a manager's total shareholding (direct / indirect) divided by total common share outstanding at the end of each year in the firm. The managers are chief executive officers, chairman /executive chairman in our sample, whereas, institutional investors in Malaysia are local fund managers, Employee Provident Fund Board, and other government-linked investment agencies. We do not include the warrants and options as well as indirect shareholdings of the managers and institutional investors. We also exclude total board members ownership in the firm because we are interested in managerial risk aversion not the entire board as in previous studies. We use ratio of managers and institutional investors' shareholdings denoted by MAN and INST.

\section{Sample and methodology}

\subsection{Sample}

The data on the foreign currency and interest rate derivative instruments were obtained from the firms' annual reports. These annual reports were downloaded from Bursa Malaysia Company Announcement Webpage in PDF format. To locate a firm's disclosure on the notional amount of the foreign currency and interest rate derivatives such as forward contracts, the "Find" option in PDF was used to search for key terms such as "instrument", "derivatives" and "hedges" in the downloaded PDF files. These key terms were found in the section titled "Financial Risk Management and Policies" in notes to the accounts in the annual reports. We included in our investigation the financial -year end notional amount of foreign currency derivatives (in Ringgit Malaysian) such as the Forward and Future contracts, whereas, for interest rate derivates, Forward and Swaps contracts. Othman and Ameer (2009) report that Forward contracts are used in high proportion to hedge market risks by Malaysian companies followed by Future and Swap contracts. Out of 427 firms, only 112 firms met our criteria of non-missing data on derivatives and other variables and therefore sufficient firm-year observations 
over the period, 2003 - 2007. The five-year period choice is somewhat similar to earlier studies on derivatives in the developed countries (see e.g., Singh and Upneja, 2007; Allayannis and Weston, 2001). It is worth mentioning that our coverage is better than previous studies such as Linsley and Shrives (2006) who studied 79 UK firms listed within FTSE 100 in 2001 and Nguyen and Faff (2003) 77 Australian firms in 1999. Table 1 shows usage of derivatives according to industry and the type of hedging instrument used to hedge foreign exchange and interest rate risk.

Table 1 show that out of 427 firms, only 112 firms disclose the use of foreign currency and interest rate derivatives. This percentage is lower than those figures reported for the developed countries in the previous studies (see Allayannis and Ofek, 2001). Malaysian firm seem to prefer the customization and flexibility of Forward foreign exchange contracts over other standardized foreign exchange Options and Future contracts. The rest of the firms have used in different proportion the Forward and Swaps contracts for foreign exchange and interest rate risk management respectively (Othman and Ameer, 2009). It is important to point out here that all the sample firms except banks disclosed that trading in derivatives is not allowed under their financial risk management policy.

Table 2 shows the summary statistics of the main variables that are used in multivariate analysis in this paper. We separate the firm-year observations into firms with foreign sales and without foreign sales. We argue that, such as separation could explain different motives of hedging, for instance, firms without foreign sales are more likely to use derivatives for payments of imports and hedge against changes in the interest rates. On the other hand, firms with foreign sales are more likely to use derivatives for shield future cash flows in foreign currencies from adverse movements in the foreign exchange rates. Besides this apparent economic rationale for hedging, it would be valuable to explore the connection between managerial ownership and derivatives usage, i.e., when foreign sales are zero, manager's incentive to hedge might also be related to their personal wealth maximization because poorly diversified managers with linear wealth function have incentive to engage in more hedging.

On average, firms with foreign sales $>0$ are large firms have higher use of derivatives, DPS, CAPEX and INST than firms with foreign sales $=0$. It is noteworthy that among latter firms' managers have higher shareholdings than former firms suggesting that manager's wealth function is linear and increase in equity investment in the firm does lead to hedging. While in the case of former firms, it is plausible that due to monitoring by the institutional investors and pressure for good performance, managers have incentives to engage in hedging activities. Although it can be argued that among firms with foreign sale $=0$, hedging practices of the firms might be driven by managers' personal wealth maximization objective but we cannot test this proposition due to following reasons. These firms might include those firms that have only import payments to hedge or those firms which have only interest rate risk exposure to hedge. Since sample firms do not report import expenses and there are limited number of firm-level observations on foreign floating rate debt.

The correlation coefficients reported in Table 3 seem to suggest that the total amount of derivatives used by the firms have significant positive correlation with firms' growth options, foreign sales, size and dividends per share. We do not find any correlation between derivatives and ownership, financial risk and other growth options variable such as $P E$ ratio. There is significant positive correlation between variables used as proxy for growth options. There is possibility that including all of these variables together in our model might lead to multi-collinearity problem, therefore, we use only those variables in our multivariate analysis that does not exhibit this problem using standard multi-collinearity test such as VIF test.

\subsection{Methodology}

There are two distinct methodologies that have been used to examine firms' hedging decisions- first, using a dummy variable approach whereby all hedging firms are denoted by 1 and non-hedging firms by 0 , and then a logistic estimation method is used to model the probability of hedging decision against non-hedging (see e.g., Pennings, 2002; Whidbee and Wohar, 1999). Second, notional amounts or gross value of derivatives has been to explain the amount of derivatives used by the firms in a linear regression framework (see e.g., Singh and Upneja, 2007; Fok et al, 1997). The main objective of this paper is to examine the determinants of foreign currency and interest rate derivatives for which second approach seems more appropriate. We specify and estimate following regression model for all firms (Note 1):

$$
\begin{aligned}
N D E R_{i, t}=\beta_{0} & +\beta_{1} D E B T_{i, t}+\beta_{2} M T B_{i, t}+\beta_{3} Q A_{i, t} \\
& +\beta_{4} F S_{i, t}+\beta_{5} C F V_{i, t}+\beta_{6} T A X L_{i, t}+\beta_{7} M A N_{i, t}+\beta_{8} I N S T_{i, t}+\varepsilon_{i, t}
\end{aligned}
$$

where for a firm $i \quad N D E R$ denotes the notional amount of total foreign exchange and interest rate derivatives outstanding (in RM); $D E B T$ is long-term debt to total assets ratio; $M T B$ denotes the ratio of the sum of market 
value of equity and book value of debt to total assets; $Q A$ is defined as ability to convert assets into cash quickly; $F S$ is the ratio of the foreign sales to total sales at the end of year; $C F V$ denotes the cash flow volatility measured by standard deviation of operating income before depreciation; TAXL denotes tax losses obtained from; MAN and INST shows the shareholdings of a manager and institutional investors as ratio of total outstanding common shares at the year-end (Note 2). $\varepsilon_{i, t}$ is the error term having the following properties: $E\left(\varepsilon_{i, t}\right)=0$. All variables are calculated as at the end of year $t$ and in nominal terms.

\section{Results}

We estimate Eq. (1) using the ordinary least square estimation method by pooling all firm-year observations in Eviews 6.0. Although the Adjusted $\mathrm{R}^{2}$ is relatively similar to Singh and Upneja (2001) study on the US lodging firms (Note 3), we cannot compare the results with other US studies, for instance, (Allayannis and Ofek, 2001) (Note 4). However, the diagnostics such as the White test for the Heteroskedasticity in the residuals and the Lagrange Multiplier test for serial correlation in the residuals suggests that there is no evidence of Heteroskedasticity and serial correlations in the residuals. Furthermore, we also report Ramsey Reset test statistics which also shows that the model is correctly specified. We interpret correct sign on the regression coefficients as evidence in favor of the hypothesized relationship as discussed above in section 2.

The estimated regression coefficients show that most variables have expected signs except $D E B T$, and TAXL (see Table 4). Consistent with previous studies, firms' foreign sales, liquidity, growth options, managerial ownership and size are related to greater level of hedging. In particular, our results seem to suggest that firms with higher level of foreign sales and growth opportunities are active users of the derivatives, while, firms with higher ratio of quick assets do not use derivatives but tend to use excess liquidity to absorb unpredicted changes in the foreign currency and interest rate risks. We do not find predicted relationship for tax losses variable which might be due to lack of tax concavity.

\subsection{Ownership effects}

The ownership variables are also significant explanatory variables in our estimation results. The coefficient on $M A N$ is significantly positive at 1 percent level of significance, suggesting that increase in managerial ownership leads to higher usage of derivatives because managers try to minimize risk affecting the return on their investment in the firms. Whidbee and Wohar (1999, p.252) suggest that managers benefit from hedging by reducing the uncertainty associated with the level of their wealth (as function of firms value) and by reducing the likelihood that they are disciplined for poor firm performance. Effective monitoring mechanism tend to make a manager's utility function concave at low level of firms value and as argued by Smith and Stulz (1985), managers with concave wealth functions are likely to hedge as much as possible. INST has a significant negative sign indicating that institutional investors in Malaysia do not invest in firms prone to foreign and interest rate risks. These findings are somewhat similar to Solomon et al. (2002) who report that institutional investors in the UK have lower shareholdings in the firms with high level of risk disclosures.

\subsection{Industry effects}

We also incorporate the industry effects in our model to test whether foreign exchange exposure faced by different industry sectors lead to different level of hedging. We use dummy variable equal to 1 for four industry sectors - consumer products, industrial products, trading/services, and plantation denoted by $C P, I P, T S$, and $P L$ respectively and 0 otherwise. We use financial sector denoted by $F I$ as base category. The results are shown in Table 4. There is strong evidence of industry effects as shown by significant positive coefficients on the $C P, T S$ and $P L$ respectively.

\section{Conclusion}

The aim of this paper has been to extend knowledge about the factors that influence the demand for foreign exchange and interest rate derivatives in developing countries for which there are only a limited number of studies. The main findings of the paper seems to suggest that there is a strong relationship between the use of derivatives and firms' foreign sales, liquidity, growth options, managerial ownership and size in Malaysia. In particular, our results suggest that firms with higher foreign sales volume and growth opportunities are active users of the derivatives.

Our findings also seem to indicate that there might be different incentives to hedge foreign exchange risk among Malaysian firms (Note 5). Among the firms, having no foreign sales but higher managers' shareholdings, managers have incentives to hedge because of personal wealth maximization objective. While in the case of 
firms with foreign sales and lower managers' shareholdings, the institutional investors' pressure for good performance give managers' incentives to engage in hedging activities.

Our findings confirms that factors that significantly affect hedging practice of US firms as reported by Allayannis and Ofek (2001) also seem to explain the use of derivatives by Malaysian firms. The firm specific factor such as, size of the firm seem to have stronger influence on derivatives use. Our paper has several important implications for managers and financial regulators. At present Malaysian managers are risk averse (Note 6) and do not understand the "upside" of taking position in derivatives market. They should seek the help of consultants and professional bankers to ascertain the risk appetite of their organization before taking the position in the derivatives market. We propose that future research should seek to establish does firm size also affect the use of other types of derivatives not studied in this paper. At the same time, there is a need for research on the strategy and outlook of banks' treasury departments providing these derivative products.

\section{References}

Alizadeh, H.A, Nomikos, K.N. and Pouliasis, K.P. (2008). A Markov regime switching approach for hedging commodities. Journal of Banking and Finance, 32(9), 1970-1983.

Allayannis, G. and Ofek, E. (2001). Exchange rate exposure, hedging and the use of foreign currency derivatives. Journal of International Money and Finance, 20, 273-286.

Allayannis, G. and Weston, J.P. (2001). The use of foreign currency derivatives and fair market value. Review of Financial Studies, 14, 263-276.

Bartram, M.S. (2008). What lies beneath: Foreign exchange rate exposure, hedging and cash flows. Journal of Banking and Finance, 32(8), 1508-1521.

Bartram, M.S., Brown, G.W. and Fehle, F.R. (2003).International Evidence on Financial Derivatives Usage. Working Paper, Lancaster University, Lancaster, United Kingdom.

Bessembinder, H. (1991). Forward contracts and firm value: Investment incentive and contracting effect. Journal of Financial and Quantitative Analysis, 26(4), 519-532.

Carcano, N. Foresi, S. (2008). Hedging against interest rate risk: Reconsidering volatility-adjusted immunization. Journal of Banking and Finance, 21(2), 127-141.

Chalmers, K. and Godfrey, J.M. (2000). Practice versus Prescription in the Disclosure and Recognition of Derivatives. Australian Accounting Review, 11(2), 40-50.

Chalmers, K. (2001). The Progression from Voluntary to Mandatory Derivative Instrument Disclosures-Look Who's Talking, Australian Accounting Review, 11(1), 34-45.

Fok, C.W.R., Carroll, C., Chiou, C.M. (1997). Determinants of Corporate Hedging and Derivatives: A Revisit. Journal of Economics and Business, 49, 569-585.

Froot, K, Scharfstein, D. and Stein, J. (1993). Risk management: Coordinating corporate investment and financing policies. The Journal of Finance, 48, 1629-1658.

Géczy, C, Bernadette A. M and Schrand, C. (1997). Why firms use currency derivatives. The Journal of Finance, 52, 1323-1354.

Graham, R.J. Smith, and C.W. Jr. (1999). Tax Incentive to Hedge. The Journal of Finance, 54(6), 2241-2262.

Hagelin, N. Holmen, M. and Prambord, B. (2006). Family ownership, dual-class shares and risk management. Global Finance Journal, 16, 283-301.

Hagelin, N. (2003). Why Firms Hedge With Currency Derivatives: An Examination of Transaction and Translation Exposure. Applied Financial Economics, 13, 55-69.

He, J. and Ng, K. L. (1998). The Foreign Exchange Exposure of Japanese Multinational Corporations. The Journal of Finance, 53(2), 733-753.

Lien, D. and Yang, L. (2008). Asymmetric effect of basis on dynamics of future hedging: Empirical evidence from commodity markets. Journal of Banking and Finance, 32(2), 187-198.

Linsley, M.P. and Shrives, J.P. (2006). Risk reporting: A study of risk disclosures in the annual report of UK Companies. The British Accounting Review, 38(4),387-404.

Malaysian Accounting Standard Board. (2005). Financial Reporting Standard FRS 132 Financial Instruments: Disclosure and Presentation. Malaysian Accounting Standards Board, Kula Lumpur. 
Myers, S. C. (1977).Determinants of corporate borrowing. Journal of Financial Economics, 5(2), 147-175.

Othman, R., Ameer, R. (2009). Market Risk Disclosure: Evidence from Malaysian Listed Firms. Journal of Financial Regulation and Compliance 17(1), 57-69.

Nance, D. R., Smith C. W. Jr. and Smithson, C.W. (1993). On the Determinants of Corporate hedging. The Journal of Finance, 48, 391-405.

Nguyen, H. and Faff, R. (2003). Can the use of foreign currency derivatives explain variations in foreign exchange exposure? Evidence from Australian Companies. Journal of Multinational Financial Management, 13(3), 193-215.

Pennings, E.M.J. (2002). Pulling the trigger or not: Factors affecting the behavior of initiating a position in derivatives markets. Journal of Economic Psychology, 23(2), 263-278.

Singh, A. and Upneja, A. (2007). "Extend of Hedging in the US lodging industry", Journal of Hospitality Management, 26(4), 764-776.

Smith, C. W. and Stulz, R. (1985). The determinants of firms' hedging policies. Journal of Financial and Quantitative Analysis, 20, 391-405.

Solomon, J.F., Solomon, A., Norton, S.D. and Joseph, N.L. (2000). A conceptual framework for corporate risk disclosure emerging from the agenda for corporate governance reform. British Accounting Review, 32(4), $447-478$.

Whidbee, A.D. and Wohar, M. (1999). Derivative activities and managerial incentives in the banking industry. Journal of Corporate Finance, 5, 251-276.

Notes

Note 1 . We include all firms those having foreign sales $=0$ and foreign sales $>0$.

Note 2. Other potential proxies have not been used due to issue of multi-collinearity, see Table 3.

Note 3. Singh and Upneja (2001, table 5) reported R2 of 0.251.

Note 4. The R2 reported by Allayannis and Ofek is derived from Probit model and therefore not exactly comparable with our Adjusted R2 shown here.

Note 5. The estimation results are all firms having no foreign sales and foreign sales.

Note 6. There are only 30 firms which have reported the use of derivatives over the sample period. 
Table 1. Distribution of Sample and Usage of Derivatives

This table shows the distribution of the sample firms by industry and use of derivatives.

\begin{tabular}{|c|c|c|c|c|c|c|c|c|c|}
\hline Firms in the sample & Construction & $\begin{array}{l}\text { Consumer } \\
\text { Products }\end{array}$ & $\begin{array}{l}\text { Financial } \\
\text { Institutions }\end{array}$ & $\begin{array}{l}\text { Industrial } \\
\text { Products }\end{array}$ & Plantation & Property & Technology & $\begin{array}{l}\text { Trading/ } \\
\text { Services }\end{array}$ & Total \\
\hline No of firms with annual reports 2003-2007 & 14 & 45 & 26 & 100 & 21 & 26 & 113 & 82 & 427 \\
\hline Firms reporting use of FCDs 2003-2007 & 2 & 36 & 13 & 42 & 28 & 5 & 5 & 22 & 153 \\
\hline Firms with complete data 2003-2007 & 0 & 30 & 8 & 35 & 15 & 4 & 1 & 17 & 110 \\
\hline \multicolumn{10}{|l|}{ Usage of derivatives $2003-2007$} \\
\hline Forwards Contracts & - & 25 & $-*$ & 32 & 13 & 3 & 3 & 4 & 80 \\
\hline Interest rate Swap Contracts & 1 & 0 & $-*$ & 1 & 2 & 1 & - & 2 & 7 \\
\hline Forwards and Interest rate Swap Contracts & 1 & 5 & $-*$ & - & - & - & - & 1 & 7 \\
\hline Total & 2 & 30 & $-*$ & 33 & 15 & 4 & 3 & 7 & 94 \\
\hline
\end{tabular}

*- 8 financial institutions -banks in the sample firms have entered into Forward, Swaps, Futures, Options contract between $2003-2007$. 
Table 2. Descriptive Statistics

This table shows the descriptive statistics of the explanatory variables. DPS, is dividend per share; QA, is the ratio of current assets less inventories divided by total liabilities; DEBT, is the ratio of long-term debt to total assets; PE, is the price earnings ratio; CAPEX, is the ratio of capital expenditure to total sales; $M T B$, is the ratio of the sum of the market value of equity and book value of debt to total assets; $C F V$ is the standard deviation of operating income before depreciation; MAN and INST, are manager's and institutional investors shareholding; $D E R V$, is the notional amount of derivatives; $E A R$, is total earnings before extraordinary items; $T A$, total assets ; $M V$, is the market value of firm at the end of year.

\begin{tabular}{|c|c|c|c|c|c|}
\hline All firms & Mean & Median & Std. & Minimum & Maximum \\
\hline$D P S$ & 0.1205 & 0.0665 & 0.1404 & 0.0000 & 0.6480 \\
\hline$Q A$ & 0.9361 & 0.5909 & 1.0572 & 0.0000 & 5.3531 \\
\hline$D E B T$ & 0.0953 & 0.0572 & 0.1078 & 0.0000 & 0.4832 \\
\hline$P E$ & 20.5620 & 13.3700 & 50.3119 & -160.4400 & 488.0000 \\
\hline CAPEX & 0.1641 & 0.0550 & 0.3835 & 0.0008 & 2.7395 \\
\hline MTB & 1.3758 & 1.0439 & 1.1190 & 0.0000 & 6.2333 \\
\hline$C F V$ & 1.2709 & 0.5092 & 2.1778 & 0.0042 & 9.4838 \\
\hline$M A N$ & 0.0480 & 0.0034 & 0.16 & 0.0000 & 0.1626 \\
\hline INST & 0.1272 & 0.0717 & 0.15 & 0.0000 & 0.9210 \\
\hline DERV (RM millions) & 3179.09 & 37.6348 & 11026.56 & 0.0000 & 80590.8 \\
\hline EAR (RM millions) & 499.96 & 73.1010 & 966.9687 & -70.679 & 7003.01 \\
\hline TA (RM millions) & 20502 & 2,183 & 46209.21 & 86928 & 255651 \\
\hline$M V$ (RM millions) & 6786771 & 775662 & 12094544 & 244990 & 46670690 \\
\hline \multicolumn{6}{|l|}{ Foreign sales $>0$} \\
\hline$D P S$ & 0.1253 & 0.0730 & 0.1336 & 0.0000 & 0.6480 \\
\hline$Q A$ & 0.9933 & 0.6403 & 1.1074 & 0.0000 & 5.3531 \\
\hline$D E B T$ & 0.0868 & 0.0547 & 0.0940 & 0.0000 & 0.3805 \\
\hline$P E$ & 17.1311 & 14.4750 & 16.3642 & -30.0000 & 110.5300 \\
\hline CAPEX & 0.1549 & 0.0505 & 0.4070 & 0.0008 & 2.7395 \\
\hline$M T B$ & 1.4624 & 1.1167 & 1.1613 & 0.0000 & 6.2333 \\
\hline$C F V$ & 1.2979 & 0.3892 & 2.1845 & -10.0006 & 9.4834 \\
\hline$M A N$ & 0.0075 & 0.0034 & 0.0119 & 0.0000 & 0.0673 \\
\hline INST & 0.1316 & 0.0700 & 0.1690 & 0.0000 & 0.9210 \\
\hline DERV (RM millions) & 3899.69 & 37.6300 & 12387.93 & 0.0000 & 80,591 \\
\hline EAR (RM millions) & 541.9543 & 72.5980 & 996.2151 & -70.679 & $7,002.51$ \\
\hline TA (RM millions) & 22092.90 & 1620871 & 50044.02 & 154509 & 255651 \\
\hline$M V$ (RM millions) & 6974853 & 942136 & 11761655 & 29908 & 46670690 \\
\hline \multicolumn{6}{|l|}{ Foreign sales $=0$} \\
\hline$D P S$ & 0.1026 & 0.0360 & 0.1646 & 0.0000 & 0.6310 \\
\hline$Q A$ & 0.7398 & 0.5431 & 0.8497 & 0.1327 & 3.9291 \\
\hline$D E B T$ & 0.1250 & 0.0803 & 0.1442 & 0.0000 & 0.4832 \\
\hline$P E$ & 32.5700 & 10.6250 & 102.6849 & -160.4400 & 488.0000 \\
\hline CAPEX & 0.1965 & 0.1110 & 0.2900 & 0.0047 & 1.3317 \\
\hline MTB & 1.0729 & 0.6248 & 0.9096 & 0.1807 & 3.9120 \\
\hline$M A N$ & 0.0453 & 0.0330 & 0.0549 & 0.0000 & 0.1626 \\
\hline$C F V$ & 0.4653 & 0.2899 & 0.7485 & 0.0000 & 2.3562 \\
\hline INST & 0.1135 & 0.0900 & 0.1200 & 0.0000 & 0.3796 \\
\hline DERV (RM millions) & 657.1390 & 15.4078 & 1733.65 & 0.0000 & 6852.3 \\
\hline EAR (RM millions) & 353.0129 & 25.5365 & 855.94 & -70.5800 & 4067.6000 \\
\hline TA (RM millions) & 14937.83 & 523.8600 & 29052.10 & 86928.00 & 103155.50 \\
\hline$M V$ (RM millions) & 6128486 & 396366.00 & 13387511 & 24499 & 43100190 \\
\hline
\end{tabular}


Table 3. Spearman correlation results

\begin{tabular}{|c|c|c|c|c|c|c|c|c|c|c|c|c|}
\hline & $D E R V$ & $D E B T$ & $Q A$ & $M T B$ & $F S$ & $C F V$ & $M A N$ & $I N S T$ & SIZE & $D P S$ & $P E$ & CAPEX \\
\hline DERV & 1.0000 & & & & & & & & & & & \\
\hline$D E B T$ & -0.0226 & 1.0000 & & & & & & & & & & \\
\hline$Q A$ & $-0.2032^{b}$ & $-0.3213^{\mathrm{a}}$ & 1.0000 & & & & & & & & & \\
\hline$M T B$ & $0.3342^{\mathrm{a}}$ & -0.0429 & -0.0936 & 1.0000 & & & & & & & & \\
\hline$F S$ & $0.2502^{\mathrm{a}}$ & -0.0360 & $0.2683^{\mathrm{a}}$ & 0.0849 & 1.0000 & & & & & & & \\
\hline$C F V$ & 0.0151 & 0.1385 & -0.0230 & -0.0174 & 0.0606 & 1.0000 & & & & & & \\
\hline$M A N$ & -0.0704 & 0.0254 & 0.0089 & -0.1603 & 0.0197 & -0.0219 & 1.0000 & & & & & \\
\hline$I N S T$ & 0.0313 & 0.0619 & 0.0018 & 0.0868 & 0.0183 & -0.0579 & 0.0590 & 1.0000 & & & & \\
\hline$S I Z E$ & $0.2347^{\mathrm{a}}$ & $0.1910^{\mathrm{b}}$ & $-0.4513^{\mathrm{a}}$ & $0.2856^{\mathrm{a}}$ & -0.1498 & -0.1667 & $-0.3902^{a}$ & 0.0784 & 1.0000 & & & \\
\hline$D P S$ & $0.3456^{\mathrm{a}}$ & $-0.2626^{\mathrm{a}}$ & -0.0379 & $0.4207^{\mathrm{a}}$ & 0.0244 & 0.0089 & $-0.3482^{\mathrm{a}}$ & 0.0136 & $0.4995^{\mathrm{a}}$ & 1.0000 & & \\
\hline$P E$ & -0.0605 & $0.2062^{b}$ & $-0.1768^{b}$ & $0.2400^{\mathrm{a}}$ & -0.1018 & 0.0987 & -0.1187 & 0.0067 & $0.2660^{\mathrm{a}}$ & -0.1213 & 1.0000 & \\
\hline CAPEX & $-0.3010^{\mathrm{a}}$ & $0.5040^{\mathrm{a}}$ & -0.0187 & $-0.2237^{\mathrm{a}}$ & -0.1115 & -0.0494 & $-0.2257^{\mathrm{a}}$ & 0.0029 & -0.0976 & $-0.4301^{\mathrm{a}}$ & 0.0292 & 1.0000 \\
\hline
\end{tabular}

Where $^{\mathrm{a}}$ and ${ }^{\mathrm{b}}$ shows statistical significance at 1 and 5 per cent level. 
Table 4. Regression Results

This table reports the regression results. The dependent variable is $D E R V$, the notional amount of derivatives. $D E B T$ is the ratio of long-term debt to total assets; $M T B$ is ratio of the sum of market value of equity and book value of debt to total assets. $F S$ is ratio of foreign sales to total sales; $C F V$ is the standard deviation of operating income before depreciation; TAXL denotes reported tax losses; $Q A$ is the ratio of quick assets to total liabilities; $M A N$ and INST are managers and institutional investors' shareholding in a firm at the end of year $t$. SIZE is natural logarithm of total assets. Dummy variable equal to 1 for four industry sectors - consumer products, industrial products, trading/services, and plantation denoted by $C P, I P, T S$, and $P L$ respectively and keep financial sector denoted by FI as base category. The diagnostics test reported are Heteroskedasticity in residuals; serial correlation in the residuals, Ramsey RESET test, and Jarque-Berra (JB) test for normality of the residuals. $P$-values of the tests are shown in (parenthesis). The figures in the square brackets are the [t-values].

\begin{tabular}{|c|c|c|c|c|}
\hline Variable & $\begin{array}{l}\text { Expected } \\
\text { sign }\end{array}$ & $\begin{array}{c}\text { I } \\
\text { Coefficients }\end{array}$ & $\begin{array}{c}\text { II } \\
\text { Coefficients }\end{array}$ & $\begin{array}{c}\text { III } \\
\text { Coefficients }\end{array}$ \\
\hline Constant & & $\begin{array}{c}0.4675 \\
{[1.3358]}\end{array}$ & $\begin{array}{c}0.1919 \\
{[1.4623]}\end{array}$ & $\begin{array}{c}0.0726 \\
{[0.0991]}\end{array}$ \\
\hline$D E B T$ & $(+)$ & $\begin{array}{c}-1.7645 \\
{[-1.7923]}\end{array}$ & $\begin{array}{c}0.4515 \\
{[0.7041]}\end{array}$ & $\begin{array}{c}0.3392 \\
{[0.5471]}\end{array}$ \\
\hline MTB & $(+)$ & $\begin{array}{c}0.4258^{\mathrm{a}} \\
{[2.4942]}\end{array}$ & $\begin{array}{c}0.0862^{\mathrm{b}} \\
{[1.0882]}\end{array}$ & $\begin{array}{c}0.1739^{6} \\
{[1.8252]}\end{array}$ \\
\hline$F S$ & $(+)$ & $\begin{array}{c}0.4416^{\mathrm{c}} \\
{[1.9529]}\end{array}$ & $\begin{array}{c}0.9214^{\mathrm{a}} \\
{[3.6955]}\end{array}$ & $\begin{array}{c}0.8380^{\mathrm{a}} \\
{[2.9092]}\end{array}$ \\
\hline$C F V$ & $(+)$ & $\begin{array}{c}0.0078 \\
(0.0321)\end{array}$ & $\begin{array}{c}0.0170 \\
{[0.3734]}\end{array}$ & $\begin{array}{c}0.0157 \\
(0.0432)\end{array}$ \\
\hline TAXL & $(+)$ & $\begin{array}{c}0.0010 \\
(0.1235)\end{array}$ & $\begin{array}{c}0.0025 \\
(0.1358)\end{array}$ & $\begin{array}{c}0.011 \\
(0.1222)\end{array}$ \\
\hline$Q A$ & $(-)$ & $\begin{array}{c}-0.2334 \\
{[-2.1778]}\end{array}$ & $\begin{array}{c}-0.0693^{\mathrm{c}} \\
{[-1.6197]}\end{array}$ & $\begin{array}{c}-0.0443^{\mathrm{a}} \\
{[-0.8781]}\end{array}$ \\
\hline$M A N$ & $(+)$ & - & $\begin{array}{c}4.3571^{\mathrm{a}} \\
{[2.1355]}\end{array}$ & $\begin{array}{c}2.3191 \\
{[1.2330]}\end{array}$ \\
\hline INST & $(+)$ & - & $\begin{array}{l}-1.3986^{\mathrm{a}} \\
{[2.4318]}\end{array}$ & $\begin{array}{c}-1.3856^{\mathrm{a}} \\
{[-2.5877]}\end{array}$ \\
\hline SIZE & $(+/-)$ & - & $\begin{array}{c}0.0902^{\mathrm{a}} \\
{[2.0031]}\end{array}$ & $\begin{array}{c}0.0021 \\
{[0.0400]}\end{array}$ \\
\hline$I P$ & & - & - & $\begin{array}{c}-0.1252 \\
{[-0.5611]}\end{array}$ \\
\hline$C P$ & & - & - & $\begin{array}{c}0.4367^{\mathrm{a}} \\
{[2.7286]}\end{array}$ \\
\hline$T S$ & & - & - & $\begin{array}{c}0.3373^{\mathrm{b}} \\
{[1.9138]}\end{array}$ \\
\hline$P L$ & & - & - & $\begin{array}{c}0.7658 \\
{[1.3824]}\end{array}$ \\
\hline Adjusted $R^{2}$ & & $15.39 \%$ & $19.94 \%$ & $28.44 \%$ \\
\hline Log likelihood & & -203.9287 & -89.4906 & -79.3074 \\
\hline Heteroskedasticity F-test & & $\begin{array}{c}1.4534 \\
(0.1407)\end{array}$ & $\begin{array}{c}1.2471 \\
(0.2503)\end{array}$ & $\begin{array}{c}1.7053^{\mathrm{c}} \\
(0.0589)\end{array}$ \\
\hline Serial correlation, LM F-Test & & $\begin{array}{c}2.1483 \\
(0.1210)\end{array}$ & $\begin{array}{l}3.4670^{\mathrm{b}} \\
(0.0352)\end{array}$ & $\begin{array}{c}0.5219 \\
(0.4718)\end{array}$ \\
\hline Normality, JB-test & & $3.1943^{\mathrm{c}}$ & 1.8741 & $10.1046^{\mathrm{a}}$ \\
\hline RESET & & $\begin{array}{c}(0.0989) \\
0.6856 \\
(0.5056)\end{array}$ & $\begin{array}{c}(0.5432) \\
0.4320 \\
(0.1443)\end{array}$ & $\begin{array}{c}(0.0073) \\
0.5182 \\
(0.5970)\end{array}$ \\
\hline $\mathrm{N}$ & & 134 & 134 & 134 \\
\hline
\end{tabular}

